\title{
Schizofreni og suicidalitet
}

\author{
Ved Ingrid Melle og Elizabeth Barrett
}

Pasienter med schizofreni har en overdødelighet i forhold til normalbefolkningen. En av hovedårsakene er tidlig død på grunn av suicid. Som i alle andre grupper er de viktigste risikofaktorene tidligere suicidfors $ø$, rusmisbruk, depresjon og følelse av håpløshet. Suicidrisikoen er høyest de første årene etter sykdomsstart, og den ser også ut til å være høyere hos personer med god innsikt og god kognitiv fungering. God behandling ser ut til å redusere suicidrisiko, og det er også indikasjoner på at tidlig oppdaging og behandling kan ha en positiv innflytelse.

\section{Hva er schizofreni?}

Schizofreni er en alvorlig psykisk lidelse som rammer omtrent $1 \%$ av befolkningen. Det karakteristiske ved lidelsen er tilstedeværelsen av psykotiske symptomer, dvs. tegn på sviktende realitetssans. De psykotiske symptomene kan innebære at pasienten hører eller ser ting som andre ikke hører eller ser, dvs. hallusinasjoner, eller har fastholdte misoppfatninger som er vanskelig å korrigere, dvs. vrangforestillinger. Denne typen symptomer kalles noen ganger positive symptomer fordi de representerer et tillegg av noe som ikke skulle være der. De psykotiske symptomene er som regel periodevise, de kommer og går og kan være borte over kortere eller lengre tid.

Mange pasienter med schizofreni og schizofreniliknende psykoser har også andre typer problemer. En stor gruppe strever med motivasjonsmangel og initiativløshet. Fordi disse symptomene representerer et fravær av noe som normalt er til stede, kalles de negative symptomer. Sist, men ikke minst: De siste årene har vi blitt mer og mer klar over at pasienter med schizofreni også har problemer med oppmerksomhet, hukommelse og problemløsende evner. Disse symptomene kalles vanligvis kognitive symptomer og oppleves gjerne som konsentrasjonsvansker fra pasientens side.

Den årlige forekomsten av nye tilfeller av schizofreni er ganske lav, med 10-15 nye tilfeller av schizofreni og schizofreniliknende lidelser pr. 100000 pr. år. Vi vet at tilstanden ikke har én, men mange samvirkende årsaker, og at arvelig betinget sårbarhet er en svært viktig risikofaktor. Det pågår i dag en omfattende forskning på årsaker og behandling. Vi har pr. i dag behandling som kan fjerne eller dempe alvorlighetsgraden av de psykotiske symptomene, og redusere risikoen for at de skal komme tilbake. Men vi har ingen kurativ behandling som kan "reparere" den tilgrunnliggende sårbarheten.
De første symptomene på en begynnende schizofreni kommer vanligvis hos ungdom og unge voksne, oftest tidlig i 20-årene. Mange har da hatt mer uspesifikke symptomer i perioden $f \varnothing r$ det første psykotiske gjennombruddet. Denne perioden kalles prodromalfasen. Fordi tilstanden har et alvorlig forl $\varnothing \mathrm{p}$ med risiko for kronifisering hos halvparten, blir det etter hvert en relativt stor gruppe mennesker med schizofreni, vi regner med en forekomst i befolkningen på omtrent $1 \%$.

Schizofreni er den enkelttilstand det koster mest å behandle i industrialiserte land. Fordi den medfører en høy grad av uførhet, er den også en av de lidelsene som koster mest for samfunnet totalt sett. Tilstanden medf $\varnothing$ rer også betydelig lidelse for personen selv og for de som står ham eller henne nær.

\section{Suicidrisiko hos pasienter med schizofreni}

Pasienter med schizofreni har $\varnothing \mathrm{kt}$ d $\varnothing \mathrm{de}$ lighet sammenlignet med befolkningen ellers (Brown, 1997). Dette skyldes delvis en $\varnothing \mathrm{kt}$ forekomst av "vanlige sykdommer" - særlig alvorlig hjerte-kar-sykdom. Den viktigste årsaken til forh $\varnothing$ yet dødelighet er imidlertid den høye suicidraten hos disse pasientene. I noen unders $\varnothing$ kelser er forekomsten over $10 \%$, mens anslag basert på metastudier antyder en forekomst på omtrent 5 \% (Palmer, Pankratz, \& Bostwick, 2005). I tillegg er det anslått at mellom 20-40\% gjør ett eller flere suicidfors $\varnothing \mathrm{k}$, mens oppimot $80 \%$ forteller at de i perioder har hatt suicidtanker (Siris, 2001). At så mange pasienter har suicidtanker, er et alvorlig og belastende tilleggsproblem til grunnlidelsen. Suicidfors $\varnothing$ kene er ofte alvorlige med risiko for vedvarende fysiske skader. Pasienter som overlever selve fors $\varnothing$ ket, risikerer derfor å streve med ettervirkningene livet i gjennom (Harkavy-Friedman et al., 2001).

Vi vet ikke hvorfor pasienter med schizofreni har $\phi \mathrm{kt}$ risiko for suicid (Palmer et al., 2005). Det kan virke logisk å tenke at hovedårsaken ligger i belastningen ved å være syk over tid og de negative konsekvensene av sykdommen. Det er derfor noe forbausende at det særlig er pasienter som nokså nylig har blitt syke, som har høyest risiko for suicidfors $\varnothing \mathrm{k}$ og gjennomført suicid, med en tre ganger forh $\varnothing$ yet risiko (Palmer et al., 2005). Mange - anslått til mellom 15 og $25 \%$ - har allerede gjort suicidfors $\varnothing \mathrm{k}$ f $\varnothing \mathrm{r} \sin$ f $\varnothing \mathrm{rste}$ kontakt med behandlingsapparatet (Addington et al. 2004; Nordentoft et al., 2002). For enkelte er det suicidfors $\varnothing$ ket og ikke de psykotiske symptomene som er den utløsende årsaken til første gangs kontakt (Nordentoft et al., 2002). Mange oppgir også at de har hatt suicidtanker eller gjort fors $\varnothing \mathrm{k}$ i prodromalfasen, og det kan se ut som lang sykdomsvarighet før start av behandling $\varnothing$ ker risikoen (Power et al., 2003b). Hvor mange personer med schizofreni og liknende lidelser som begår suicid før noen blir klar over deres psykiske lidelse, kjenner vi ikke til.

\section{Suicidrisiko - generelle risikofaktorer}

Som hos alle andre grupper er et tidligere suicidfors $\varnothing \mathrm{k}$ den st $\varnothing$ rste risikofaktoren for seinere fors $\varnothing \mathrm{k}$ og for seinere gjennomf $\varnothing$ rte suicid (Harkavy-Friedman et al., 2001). Problemer med rusmidler er en annen allmenn risikofaktor som $\varnothing$ ker suicidrisiko (Melle \& Ringen, 2005). Mange pasienter med schizofreni er deprimerte. For mange er en depresjon et av de mest framtredende symptomene i prodromalfasen, og depresjoner er heller ikke uvanlig de første årene etter sykdomsstart. Det ser særlig ut til at depresjonsrisikoen er stor når de psykotiske symptomene begynner å slippe taket, dette kalles gjerne postpsykotiske depresjoner. Tilstedeværelsen av depresjon $\varnothing$ ker også suicidrisikoen hos pasienter med schizofreni. Dette gjelder særlig der personen har en følelse av håpløshet over egen situasjon (Haw et al., 2005). 


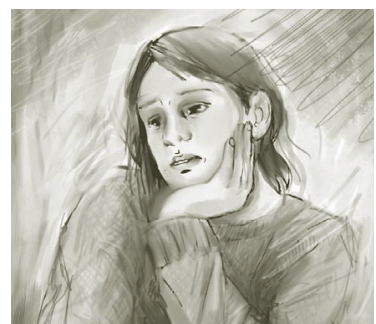

\section{Psykotiske symptomer og suicidrisiko}

Mange vil tenke at forklaringen på den $\varnothing$ kte risikoen for suicid må ligge i de psykotiske symptomene. I behandlingssituasjoner ser vi at personer som har imperative (bydende) hallusinasjoner hvor stemmen beordrer personen til å gjøre suicidfors $\varnothing \mathrm{k}$, eller personer som har forestillinger om at deres $\mathrm{d} \varnothing \mathrm{d}$ kan redde nærstående fra fare, helt klart har en situasjonsbetinget $\varnothing \mathrm{kt}$ risiko. Men de fleste unders $\varnothing$ kelser viser at det ikke er noen klar sammenheng mellom tilstedeværelsen av hallusinasjoner og vrangforestillinger i seg selv og $\varnothing \mathrm{kt}$ risiko for suicid (Haw et al., 2005).

Tvert imot kan det se ut som $\varnothing \mathrm{kt}$ innsikt $\varnothing$ ker risikoen. Med innsikt menes her en erkjennelse av at man er syk og at man har behov for behandling, koblet til en evne til å forstå at symptomene man opplever skyldes sykdommen (David, 1990). Flere unders $\varnothing$ kelser tyder på at $\varnothing \mathrm{kt}$ innsikt følges av $\varnothing \mathbf{k t}$ depresjon og $\varnothing \mathrm{kt}$ suicidrisiko (Kim et al., 2003; Mintz et al., 2004).

Men bildet er ikke entydig. Andre unders $\varnothing$ kelser tyder på at $\varnothing \mathrm{kt}$ innsikt kan redusere risiko (Turkington et al., 2002). En foreslått forklaringsmodell er at $\varnothing \mathrm{kt}$ innsikt kan føre til depresjon og håpløshet hos enkelte, men til bedre forståelse og behandlingssamarbeid hos andre (Pompili et al., 2004). Det er mulig at personens oppfatninger om langtidsutsiktene for en som rammes, kan være en mellomliggende faktor som forklarer deler av dette tilsynelatende tankekorset. Schizofreni er fortsatt en stigmatisert lidelse, hvor mange tror at personer som rammes aldri vil bli friske og må tilbringe hele livet på sykehus (Jorm et al., 1997). Reaksjonen på å bli syk selv hos en som oppfatter schizofreni på denne måten, og hos en som har en tro på at det er mulig å bli bedre og ha et godt liv på tross av sykdommen, vil trolig være svært forskjellig.

Et annet tilsynelatende tankekors er at det virker som personer med lite kognitive problemer og lite negative symptomer har høyere suicidrisiko (Kaplan \& Harrow, 1999). Det kan derfor se ut som det kliniske inntrykket av at det er de mest velfungerende pasientene - førstegangspsykotiske pasienter med god innsikt og lite kognitive og negative symptomer - som tar livet av seg, har et belegg i unders $\varnothing$ kelser.

\section{Suicidrisiko og behandling}

God behandling ser ut til å redusere suicidrisikoen (Power et al., 2003a). Selv om det ikke er vist noen klar sammenheng mellom psykotiske symptomer og suicid i seg selv, er det en helt klar mulighet for at velfungerende personer som merker at en ny psykotisk episode er under utvikling ikke orker å oppleve den voldsomme psykiske påkjenningen en gang til, og at dette kan være utløsende for suicidet. Det kan også være andre uspesifikke faktorer ved god behandling som reduserer risikoen, det å ha noen å dele tankene med, noen som bryr seg og som kan gripe inn ved behov. En rekke unders $\varnothing$ kelser viser at avslutning og avbrudd av behandling er en klar risikofaktor for suicid (Kjelsberg et al., 1991). Dette er kanskje aller tydeligst hos pasienter som har vært syke over tid. Det kan fra behandlerens side virke som om det er lite å hente ved fortsatt behandling, symptomene er like sterke og uførheten uttalt og stor på tross av gjentatte intervensjoner. Men for pasienten kan avslutning av behandlingen bety at et av de viktigste kontaktpunktene i livet blir borte. Samtidig signaliseres det at her gir vi opp, det er ingen ting å gjøre (Saarinen et al., 1999; Heila et al., 1999).

I den andre enden av behandlingsspekteret ser også behandling ut til å ha stor betydning. Prosjektet "Tidlig intervensjon ved psykose" har vist at det er mulig å redusere tiden fra første psykotiske symptom til start av behandling ved et tidlig oppdagingsprogram. Dette består av en opplysningskampanje rettet mot befolkningen, som informerer om tegn til psykotisk lidelse og om viktigheten av god behandling. Samtidig med opplysningskampanjen ble det også opprettet lavterskelteam hvor folk kunne ta kontakt uten henvisning og få hjelp i løpet av 24 timer. Pasientene som på denne måten kom tidligere i behandling, hadde lavere symptomer (Melle et al., 2004). Det viser seg at de også hadde lavere forekomst av alvorlig suicidrisiko, både når det gjaldt planer og fors $\varnothing \mathrm{k}$. $\varnothing \mathrm{kt}$ informasjon kombinert med en lavere terskel inn i behandlingssystemet kan medvirke til at personer med førstegangspsykose får hjelp f $\varnothing$ r det første suicidfors $\varnothing$ ket.

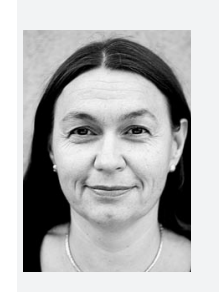

Ingrid Melle er psykiater dr.med. og forsker ved Institutt for psykiatri/Ullevål universitetssykehus, hvor hun de siste 10 årene har arbeidet med prosjektet Tidlig intervensjon ved psykose.

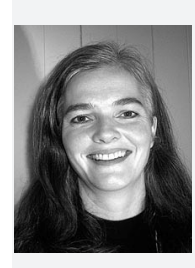

Elizabeth Barrett er psykolog og stipendiat ved Aker universitetssykehus/ Tematisk område psykoser, hvor hun arbeider med et prosjekt rettet mot suicidalitetsrisiko hos pasienter med førstegangs psykose.

\section{Referanser}

Addington, J., Williams, J., Young, J., \& Addington, D. (2004). Suicidal behaviour in early psychosis. Acta Psychiatrica Scandinavica, 109, 116-120.

Brown, S. (1997). Excess mortality of schizophrenia - A meta-analysis. British Journal of Psychiatry, 171, 502-508.

David, A. S. (1990). Insight and psychosis. Br J Psychiatry, 156, 798-808.

Harkavy-Friedman, J., Nelson, E. A., Venarde, D. F., \& Mann, J. J. (2001). Suicidal behavior in schizophrenia: What happens after the first attempt? Schizophrenia Research, 49, 14-15.

Haw, C., Hawton, K., Sutton, L., Sinclair, J., \& Deeks, J. (2005). Schizophrenia and deliberate selfharm: A systematic review of risk factors. Suicide and Life-Threatening Behavior 35[1], 50-62.

Heila, H., Heikkinen, M. E., Isometsa, E. T., Henriksson, M. M., Marttunen, M. J., \& Lonnqvist, J. K. (1999). Life events and completed suicide in schizophrenia: a comparison of suicide victims with and without schizophrenia. Schizophr. Bull., 25, 519-531.

Jorm, A. F., Korten, A. E., Jacomb, P. A. Christensen, H., Rodgers, B., \& Pollitt, P. (1997). "Mental health literacy": a survey of the public's ability to recognise mental disorders and their beliefs about the effectiveness of treatment. Med. J Aust., 166, 182-186.

Kaplan, K. J. \& Harrow, M. (1999). Psychosis and functioning as risk factors for later suicidal activity among schizophrenia and schizoaffective patients: a disease-based interactive model. Suicide Life Threat. Behav., 29, 10-24.

Kim, C. H., Jayathilake, K., \& Meltzer, H. Y. (2003). Hopelessness, neurocognitive function, and insight in schizophrenia: relationship to suicidal behavior. Schizophr. Res., 60, 71-80.

Kjelsberg, E., Eikeseth, P. H., \& Dahl, A. A. (1991). Suicide in borderline patients--predictive factors. Acta Psychiatr. Scand., 84, 283-287.

Melle, I., Larsen, T. K., Haahr, U., Friis, S.,

Johannessen, J. O., Opjordsmoen, S. et al. (2004). Reducing the duration of untreated first-episode psychosis: effects on clinical presentation. Archives of General Psychiatry, 61, 143-150.

Ref. forts. s. 15 
(Melle og Barrett: Ref. forts. fra s. 11.)

Melle, I. \& Ringen, P. A. (2005). Rus og psykoser.

In B.R.Rund (Ed.), Schizofreni (pp. 211-222).

Stavanger: Hertervig forlag.

Mintz, A. R., Addington, J., \& Addington, D.

(2004). Insight in early psychosis: a 1-year followup.

Schizophr. Res., 67, 213-217.

Nordentoft, M., Jeppesen, P., Abel, M., Kassow, P., Petersen, L., Thorup, A. et al. (2002). OPUS study: suicidal behaviour, suicidal ideation and hopelessness among patients with first-episode psychosis - One-year follow-up of a randomised controlled trial. British Journal of Psychiatry, 181, S98-S106.

Palmer, B. A., Pankratz, V. S., \& Bostwick, J. M. (2005). The lifetime risk of suicide in schizophrenia: a reexamination. Arch Gen. Psychiatry, 62, 247-253.

Pompili, M., Mancinelli, I., Girardi, P., \& Tatarelli, R. (2004). Suicide and attempted suicide in schizophrenia. European Psychiatry, 19, 170S.

Power, P. J., Bell, R. J., Mills, R., Herrman-Doig, T., Davern, M., Henry, L. et al. (2003a). Suicide prevention in first episode psychosis: the development of a randomised controlled trial of cognitive therapy for acutely suicidal patients with early psychosis. Aust.N.Z.J Psychiatry, 37, 414-420.

Saarinen, P. I., Lehtonen, J., \& Lonnqvist, J. (1999).

Suicide risk in schizophrenia: an analysis of $\mathbf{1 7}$ consecutive suicides. Schizophr. Bull., 25, 533-542.

Siris, S. G. (2001). Suicide and schizophrenia. Journal of Psychopharmacology, 15, 127-135.

Turkington, D., Kingdon, D., \& Turner, T. (2002). Effectiveness of a brief cognitive-behavioural therapy intervention in the treatment of schizophrenia. The British Journal of Psychiatry, 180, 523-527. 